\title{
PENGARUH KUALITAS PRODUK DAN HARGA TERHADAP KEPUASAN KOMSUMEN PADA MEREK CARDINAL DI RAMAYANA BUNGURASIH SIDOARJO
}

\author{
Moh. Muklis Sulaeman \\ Prodi Manajemen, Fakultas Ekonomi, Universitas Islam Lamongan \\ $\mathrm{Jl}$. Veteran No.53A Lamongan \\ Telp. ( 0322 ) 324706, Faks. ( 0322 ) 324706 \\ Email :jpim@unisla.ac.id
}

\begin{abstract}
ABSTRAK
Tujuan penelitian ini adalah 1) Mengetahui pengaruh variabel kualitas dan harga terhadap kepuasan konsumen produk cardinal di Ramayana Bungurasih 2) Menganalisis variabel yang memberikan konstribusi paling dominan dalam meningkatkan kepuasan konsumen produk cardinal di Ramayana Bungurasih. Pendekatan dalam penelitian ini menggunakan explanatory research dengan metode survei (Survey Method) dengan teknik pengambilan sample secara acak sederhana terhadap 110 responden. Teknik pengambilan data yaitu dengan angket, wawancara, survei dan dokumenter. sedangkan data yang diambil adalah data primer dan data sekunder, sedangkan teknik analisis data dengan menggunakan regresi linear berganda. Hasil penelitian menunjukkan bahwa : 1) Variabel Independen yaitu kualitas dan harga memiliki pengaruh baik secara simultan, yang ditunjukkan oleh nilai $F_{\text {hitung }}=4,889 \geq F_{\text {tabel }}=3,081$ dengan signifikansi $=0,009$, dan secara parsial dapat dilihat dari nilai masing-masing $t_{\text {hitung }}=1,173 \leq t_{\text {tabel }}=1,659$ untuk variabel kualitas (x1), dan $t_{\text {hitung }}=1,958 \geq t_{\text {tabel }}=1,659$ untuk variabel harga ( $\left.x 2\right)$, yang dapat di simpulkan bahwa variabel harga berpengaruh signifikan terhadap kepuasan konsumen, 2) Dari kedua variabel independen yaitu kualitas produk dan harga, yang memberikan kontribusi pengaruh paling dominan adalah variabel harga.
\end{abstract}

Kata Kunci : Kualitas Kerja, Harga, Kepuasan Konsumen. 


\section{PENDAHULUAN}

Dengan bertambah maraknya dunia fashion di Indonesia akibat semakin banyaknya mode-mode fashion, maka dapat melengkapi masyarakat Indonesia dalam hal memilih baju atau celana yang akan dipakainya. Pakaian merupakan kebutuhan pokok (primer) manusia, jenis pakaian yang senantiasa mengikuti akan keinginan konsumen lebih diminati, oleh sebab itu hal ini mendorong pertumbuhan industri-industri garmen untuk dapat memenuhi keinginan konsumennya, sehingga banyak bermunculan produsen-produsen baru dan industri yang mendorong tingkat persaingan dan perusahan yang melakukan segmentasi pasar. Dengan adanya persaingan tersebut, maka dapat memberikan manfaat yang positif pada masyarakat Indonesia yaitu dengan tersedianya berbagai macam pilihan merek, ukuran, bentuk dan harga sehingga memberikan banyak varian, alternatif dalam menentukan suatu pilihan. Hal ini perlu sekali diperhatikan dalam melakukan sebuah proses pemasaran, Menurut Kotler (2000:2) Pemasaran adalah suatu proses sosial yang didalamnya individu dan kelompok mendapatkan apa yang mereka butuhkan dan inginkan dengan menciptakan ,menawarkan, dan secara bebas mempertukarkan produk yang bernilai dengan pihak lain.

Hal tersebut akhirnya membuat para calon pembeli menghadapi kesulitan saat akan memilih produk mana yang akan dibeli”, persepsinya pada citra suatu produk atau merek akan muncul dan akan menjadi salah satu rangsangan atau stimulus yaitu Top Of Mind ,dalam menentukan suatu produk yang akan dibeli.

Citra merek atau produk yang paling ia ingat dan ia yakini baik yang akan ia dipilih. Dalam hal ini citra atau merek memegang peranan cukup penting, oleh karena itu saat ini banyak perusahaan saling bersaing mempengaruhi para calon pembeli untuk memilih produk mereka dengan berupaya melakukan promosi, dengan jalan :asosiasi merek, periklanan, promosi penjualan yang menarik, event yang melibatkan lansung targetting consumer , usaha penjualan dengan meningkatkan quality product dan brand imange (inovatif).

Hal tersebut digunakan untuk memperkenalkan produk baru mereka agar diketahui, diterima, diingat, dan selanjutnya diharapkan bisa dikonsumsi. Promosi bertujuan pertama untuk menciptakan pengenalan akan merek (brand awareness) di masyarakat yang kemudian diharapkan membentuk suatu citra(image). Jika citra yang baik itu terbentuk akan menjadikan suatu keuntungan bagi perusahaan karena diharapkan masyarakat akan semakin mengetahui diri atau sifat yang ada pada produk merek tersebut Promosi yang dilakukan juga berguna bagi perusahaanperusahaan yang sudah ada sejak pertama dan sudah memiliki nama baik, yaitu membangun jangka panjang untuk suatu produk, untuk mengingat kembali keberadaan produk mereka seterusnya melakukan komunikasi sehingga citra produk mereka dapat tetap terjaga dan konsumen diharapkan semakin puas dengan kualitas produk merek tersebut .

Demikian juga yang terjadi dengan perusahaan P.T. Multi Garmenjaya sebagai salah satu produsen pakaian yang cukup terkenal di Indonesia yang memproduksi pakaian dengan merek Cardinal yang terus berupaya untuk melakukan promosinya dalam menghadapi persaingan dengan perusahaan sejenis. Dalam upaya untuk terus melakukan promosinya dan dalam upaya mengadapi persaingan, perusahaan P.T. Multi Garmenjaya didalam memproduksi baju dan celana merek Cardinal senantiasa melihat akan kebutuhan para konsumennya, misalnya bentuk atau desainnya, pilihan warna, kualitas atau mutu yang baik, serta harga yang tidak terialu mahal dan juga jaringan distribusi yang luas. Dengan memperhatikan hal tersebut, maka perusahaan P.T. Multi Garmenjaya didalam memproduksi baju dan celana dengan merek Cardinal diharapkan dapat memenangkan persaingan. 
Saat ini, Cardinal menjadi salah satu produk pakaian jadi pria (men's wear) yang paling diminati di Indonesia. Bahkan sejak 1986, produk ini dipasarkan di berbagai negara, seperti Australia, Uni Emirat Arab (UEA), Bahrain, Rusia, Arab Saudi, Kuwait, Mesir dan Ethiopia. wajarlah PT Multi Garmenjaya (MG), perusahaan yang memayungi merek Cardinal, didapuk sebagai salah satu peraih Primaniyarta Award 2005 kategori pembangun merek global di sektor tekstil dan aksesori. Kini, Cardinal memiliki tiga varian produk: jins, pakaian formal dan kasual. Karena itu pula, MG membentuk tiga divisi: Casual Men's Wear, Formal Men's W segmentasi produk tiap negara ekspor berbeda-beda. Untuk mengatasi hal itu, MG tidak mengambil segmentasi yang terlalu ke atas atau terlalu ke bawah.

Jadi, sasaran produk Cardinal adalah segmen kelas menengah dan menengah-atas yang umumnya memiliki porsi atau populasi yang paling banyak dalam komposisi penduduk di negara tujuan ekspor. Sementara dari sisi target pasar, Cardinal ditargetkan untuk pria dewasa di kisaran usia 22-50 tahun. Biasanya, target ini adalah kelompok mahasiswa senior atau sarjana yang baru lulus dan mencari kerja, hingga pria dewasa dan mapan dalam usia dan karier. Adapun dari sisi positioning product, MG memosisikan produk men's wear jenis kasual dan jins yang pantas untuk dipakai bekerja dan beraktivitas sehari-hari. Mengenai harganya, disesuaikan dengan segmen pasar yang dipilih. Artinya, harga jual berada di posisi antara kelas menengah dan menengah atas.

$\begin{gathered}\text { Menerbitkan katalog, memberikan } \\ \text { kepada pembeli, }\end{gathered}$
hadiah langsung $\begin{aligned} & \text { perangan } \\ & \text { menyelenggarakan acara bekerja sama dengan }\end{aligned}$
Yang tak kalah menarik upaya promosi. MG
kerap mengikuti berbagai pameran, membuka
website, toko-toko, dan memberikan fasilitas
gerai ke pihak department store. Slogan citra
(tag line) promosinya the ultimate choice
dimaksudkan untuk menggambarkan
keunggulan merek ini di antara produk-
produk lain sejenis. Untuk mendukung
sejumlah upaya di atas, strategi distribusi jelas

penting. MG memilih bermitra dengan kalangan department store, pusat perbelanjaan, mal ataupun toko-toko yang terkenal di negara tujuan ekspor.

\section{METODE PENELITIAN}

Penelitian ini dilakukan dengan menggunakan jenis penelitian konklusif. Penelitian konklusif adalah riset yang dirancang untuk membentuk membuat keputusan dalam menentukan, mengevaluasi, serta memilih rangkaian tindakan yang harus diambil pada situasi tertentu (Malhotra, 2004:90). Dalam hal ini, digunakan untuk memahami variabel mana yang mempengaruhi (variabel independen) dan variabel mana yang merupakan akibat (variabel dependen). Dalam hal ini yang merupakan variabel bebas yaitu kualitas produk $\left(\mathrm{X}_{1}\right)$ dan harga $\left(\mathrm{X}_{2}\right)$. Sebaliknya, variabel dependen (Y) yaitu kepuasan pelanggan.

Lokasi penelitian ini adalah lokasi yang dijadikan peneliti untuk memperoleh data penelitian melalui penyebaran kuesioner kepada responden. Adapun lokasi penelitian yang dimaksud adalah merek cardinal di ramayana bungurasih - sidoarjo.

Ramayana Lestari Sentosa Tbk. Membuka cabang di Bungurasih yang terletak di Komplek Pertokoan Taman Bungurasih Jl. Letjen Sutoyo Waru-Sidoarjo

Adapun populasi dalam penelitian ini bersifat infinite artinya jumlah populasi yang diteliti tidak terhingga. ramayana bungurasih - Sidoarjo dipilih karena merupakan tempat yang lebih banyak didatangi konsumen dari golongan menengah kebawah hingga menengah ke atas (segmen pasar terbesar cardinal) yang berada diramayana bungurasih - sidoarjo.

Adapun karakteristik populasi yang menjadi target penelitian ini adalah sebagai berikut :

1. Konsumen Cardinal di Ramayana Bungurasih - Sidoarjo.

2. Responden berusia minimal 16 tahun karena dianggap responden dengan batasan umur diatas dapat memahami 
maksud dari kuesioner dan menilai pernyataan kuesioner dengan baik. Hal

\begin{tabular}{|c|c|c|}
\hline Variabel & Alpha Cronbach & Keterangan \\
\hline $\mathrm{X}_{1}$ & 0,927 & Reliabel \\
$\mathrm{X}_{2}$ & 0,858 & Reliabel \\
$\mathrm{Y}$ & 0,851 & Reliabel \\
\hline
\end{tabular}

ini mengacu pada siklus hidup manusia bahwa usia remaja lanjut dimulai sejak usia 16 tahun (Sumarwan, 2004:199).

3. Minimal Pelanggan telah membeli produk Cardinal sebanyak 2 kali.

Karena jumlah populasi yang diteliti tidak diketahui, maka metode pengambilan sampel yang digunakan adalah accidental sampling yaitu teknik penentuan sampel berdasarkan kebetulan/insidental bertemu dengan peneliti dapat digunakan sebagai sampel, bila dipandang orang yang kebetulan ditemui itu cocok sebagai sumber data. bahwa semakin besar sampelnya maka kecenderungan lebih representatif dan hasilnya lebih digeneralisir, maka ukuran sampel dapat diterima tergantung pada jenis dari penelitiannya, yaitu secara minimum tolak ukuran untuk penelitian deskriptif yaitu sekurang-kurangnya 100 sampel atau $10 \%$ dari populasi. Sehingga peneliti menentukan ukuran sampel pada penelitian sebesar 100 . Jumlah tersebut ditentukan berdasarkan pendapat Sugiono ukuran minimal sampel yang digunakan adalah 100. Untuk mengantisipasi apabila terdapat data yang tidak sesuai dengan penelitian, maka ditambahkan $10 \%$ dari jumlah sampel minimal yang diambil. Oleh karena itu, pada penelitian ini mempergunakan sampel sebesar 110 (Sugiyono, 2010:84-86).

Metode anaisis yang digunakan adalah uji validitas, uji reliabilitas, uji asumsi klasik, uji regresi berganda, uji t dan uji F.

\section{PEMBAHASAN}

Hasil anaisis perhitungan statistic adalah sebagai berikut :

1. Berdasarkan hasi uji validitas, maka dapat diketahui bahwa data yang digunakan adalah valid karena memiliki nilai signifikansi $>0,05$.

2. Hasil uji reliabilitas diperoleh data sebagai berikut:

Berdasarkan hasil diatas dapat diketahui bahwa nilai reliabilitas yang dicapai pada semua variable $>0,61$ yang artinya data yang digunakan dalam peneitian ini reliable.

3. Uji Asumsi Klasik

a. Uji Normalitas

Hasil pengolahan SPSS yang menunjukkan grafik dari Normal Probability Plot adalah sebagai berikut :

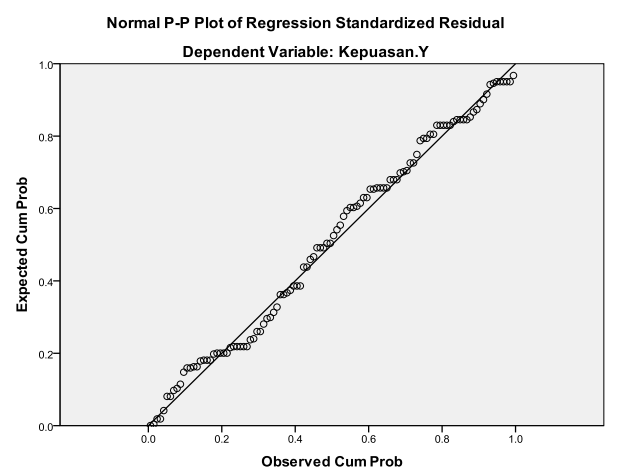

Dari grafik Normal Probability Plot dapat diketahui bahwa pada grafik tersebut terdapat titik-titik menyebar di sekitar garis diagonal dan penyebarannya terlihat mengikuti arah garis diagonal. Dengan demikian model regresi yang digunakan oleh peneliti layak dipakai karena memenuhi asumsi normalitas.

b. Uji Heteroskedastisitas

Untuk melihat ada tidaknya heteroskedastisitas bisa kita lihat pada gambar grafik scatterplot dibawah ini

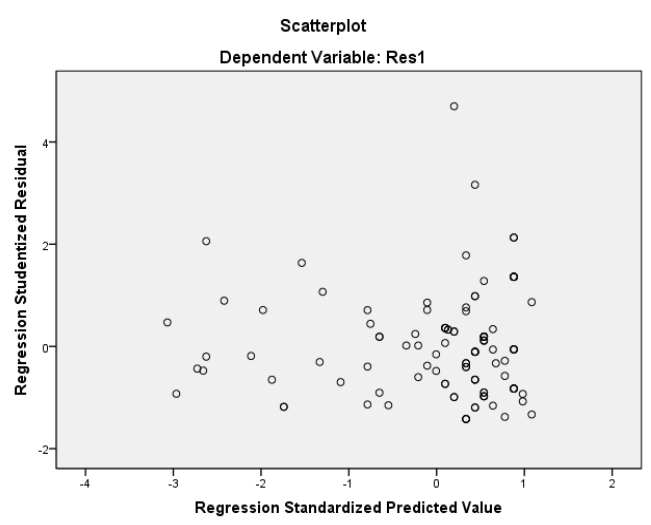


apabila diamati dari gambar diatas terdapat titik-titik menyebar tidak beraturan serta penyebarannya tidak terjadi pola yang menandakan tidak terjadi heteroskedastisitas.

c. Uji Multikolinearitas

Dari hasil uji multikolinearitas diketahui bahwa nilai-nilai toleransi yang diperoleh $>0.1$, dan nilai VIF yang diperoleh untuk masing-masing variabel bebas < 1.0, sehingga menunjukkan tidak adanya gejala multikolinearitas.

4. Analisis Regresi Linier Berganda

Berdasarkan hasil pengolahan SPSS yang disajikan pada table diatas, maka persamaan regresi linier berganda adalah sebagai berikut:

$$
Y=2,309+0,101 X_{1}+0,216 X_{2}
$$

Keterangan :

Y : Kepuasan Konsumen

$\mathrm{X}_{1}:$ Kualitas

$\mathrm{X}_{2}$ : Harga

5. Uji Hipotesis

a. Uji t

Dari hasil analisis Uji t di peroleh hasil sebagai berikut:

1. Variabel Kualitas (x1), nilai yang diperoleh adalah sebesar $t_{\text {hitung }}$ $(1,173) \leq t_{\text {tabel }}(1,982)$. Sehingga dapat dikatakan bahwa factor kualitas tidak berpengaruh signifikan terhadap kepuasan komsumen (Y).

2. Sedangkan variabel harga (x2), nilai yang diperoleh adalah sebesar $t_{\text {hitung }}(1,958) \geq t_{\text {tabel }}$ $(1,659)$. Sehingga dapat dikatakan bahwa factor harga berpengaruh signifikan terhadap kepuasan konsumen (Y). b. Uji F

Berdasarkan hasil analisis yang diperoleh nilai $F_{\text {hitung }}=4,889$ sedangkan nilai $F_{\text {tabel }}$ dapat dilihat pada table statistic (lihat lampiran) pada tingkat signifikansi 0,05 dengan df1 (jumlah variable -1$)=2$, dan df2 (n-k-1) atau 110-4-1 = 107 (n adalah jumlah data dan $\mathrm{k}$ adalah jumlah variable independen), hasil uji $F_{\text {tabel }}$ diperoleh nilai sebesar, jadi dapat disimpulkan nilai $F_{\text {hitung }}(4,889)>$ $F_{\text {tabel }}(3,081)$ yang berarti dapat diartikan bahwa variabel bebas yaitu kualitas (X1), harga (X2), secara simultan/bersamaan berpengaruh terhadap kepuasan konsumen produk cardinal di ramayana bungurasih (Y).

\section{KESIMPULAN DAN SARAN}

Setelah melalui kajian analisis dan pembahasan secara sistematis dan detail, maka dapat diambil kesimpulan bahwa:

1. Variabe kualitas dan harga secara simultan / bersama berpengaruh yang signifikan terhadap kepuasan konsumen produk cardinal di Ramayana Bungurasih. Hal ini dibuktikan dengan nilai $F_{\text {hitung }}(4,889)$ $>\mathrm{F}_{\text {tabel }}(3,081)$

2. Variabel kualitas secara parsial tidak memberikan pengaruh yang signifikan terhadap kepuasan konsumen. Hal ini dibuktikan dengan perolehan nilai $t_{\text {hitung }}(1,173)<t_{\text {tabel }}(1,982)$. Sedangkan variabel harga secara parsial memberikan pengaruh yang signifikan terhadap kepuasan konsumen. Ini dibuktikan dengan perolehan nilai $t_{\text {hitung }}(1,958) \geq \mathrm{t}_{\text {tabel }}$ $(1,659)$.

3. Dari kedua variabel bebas yaitu kualitas produk dan harga, ternyata variable yang memberikan kontribusi dominan adalah variable harga.

\section{SARAN-SARAN}


Berdasarkan hasil penelitian tersebut di atas, maka saran yang bisa diberikan adalah:

1. Perlu memberikan diskon kepada konsumen dengan tidak mengesampingkan perhitungan penetapan harga sesuai standart.

2. Tetap menjaga kualitas produk agar konsumen tetap yakin bahwa produk cardinal adalah berkualitas.

3. Perlu juga meningkatkan pelayanan extra untuk menjaga hubungan konsumen dengan produsen, sehingga konsumen merasa nyaman untuk berbelanja produk cardinal di Ramayana Bungurasih.

\section{DAFTAR PUSTAKA}

Algifari, 2000. Analisis Regresi : Teori Konsumen \& Solusi. Edisi 2. Yogyakarta: BEFE.

Arikunto, Suharsimi2010, Prosedur Penelitian Suatu Pendekatan Praktik, Cetakan Keempat belas, Rineka Cipta, Jakarta.

Butlle, Francis.2007 .customer Relationship Manajement. Edisi Pertama Terjemahan Arif Subiyanto. Jakarta : Banyumedia Publishing.

Durianto, Darmadi dan Tony Sitinjak. 2001. Strategi Menaklukkan Pasar, melalui Riset ekuitas dan perilaku merek. Jakarta: penerbit PT. Gramedia Pustaka Utama

Ferrinadewi, 2008. Merek dan Psikologi Konsumen ; Implikasi pada Strategi Pemasaran. Yogyakarta.

Griffin, jill. 2005 Customer Loyalty: menumbuhkan \& mempertahankan Kesetiaan pelanggan. Edisi Revisi Dan Terbaru. Jakarta : Penerbit Erlangga

Hasan, Ali. 2008. Marketing. Media Pressindo. Yogyakarta.

Hatane, Samuel Foedjiawati .2005. Pengaruh kepuasan Konsumen Terhadap Kesetiaan Merek.(7):74-82.

Didit darmawan ,2009. dasar - dasar pemasaran .(2000:02)
Kotler,Philip. 2003. Manejemen Pemasaran. Edisi Kesebelas. Jilid 2. Terjemahan oleh Benyamin Molan. 2005. Jakarta: PT Indeks Kelompok Gramedia.

Kotler,Philip dan Keller. 2006. Manejemen Pemasaran. Edisi Kedua belas. Jilid 1. Terjemahan oleh Benyamin Molan. 2007. Jakarta: PT Indeks Kelompok Gramedia.

Kotler, Philip. 2009. Manajemen Pemasaran. Edisi Ketiga belas. Jilid 1. Terjemahan oleh Bob Sabran, MM. Penerbit Erlangga.

Kotler, Philip. 2009. Manajemen Pemasaran. Edisi Ketiga belas. Jilid 2. Terjemahan oleh Bob Sabran, MM. Penerbit Erlangga.

Lupiyoadi, Rambat dan A.Hamdani. 2006. Manajemen Pemasaran jasa. Jakarta: Salemba Empat.

Maholtra, Naresh K.2004.Riset pemasaran Pendekatan Terapan.Edisi Keempat. Jilid 1. Terjemahan oleh Soleh Rusyadi Maryam.2009.Jakarta Indeks Kelonpok Gramedia.

Maholtra, Naresh K.2004.Riset pemasaran Pendekatan Terapan.Edisi Keempat. Jilid 2. Terjemahan oleh Soleh Rusyadi Maryam.2005.jakarta Indeks Kelonpok Gramedia.

Mowen, Jhon. C dan Minor, Michael. 2001. Perilaku Konsumen .Edisi kelima. Jilid 2 .Terjemahan oleh lina salim.2002. Jakarta: PT penerbit Erlangga.

Setiadi. J Nugroho. 2003 Perilaku Konsumen Konsep Implikasi Untuk Strategi Dan Penelitian Pemasaran Jakarta: Prenada Media.

Simamora, Bilson. 2004. Panduan Riset Perilaku Konsumen. Jakarta : gramedia Pustaka Utama.

Soemanagara. 2008. Strategic Marketing Communication Konsep Strategis dan Terapan. Bandung: CV Alfabeta.

Sugiyono. 2010. Metode Penelitian Bisnis (Pendekatan Kuantitatif, Kualitatif dan R \& D). alfabeta. Bandung. 
Sugiyono 2010, Statistika Untuk Penelitian,

Cetakan Ketujuh belas, Alfabeta, Bandung.

Sumarwan, Ujang. 2004.Perilaku Konsumen

Teori dan Penerapannya dalam Pemasaran.Bogor : Penerbit Ghalia Indonesia.

Sutisna. 2002. Perilaku Konsumen dan komunikasi Pemasaran. Bandung: PT. Remaja Rosdakarya.

Swasta, Basu dan Irawan. 2005. Manajemen Pemasaran Modern. Yogyakarta: Liberty

Tjiptono, fandy dkk.2008. Pemasaran Strateggik Yogyakarta : Penerbit Andi. 